\title{
Human Capital and Aggregate Income Differences in Mexico
}

\author{
Jorge N. Valero-Gil \\ Facultad de Economía, Universidad Autónoma de Nuevo León \\ Magali Valero ${ }^{1}$ \\ University of Michigan at Dearborn
}

\section{This Version: December 2020}

This article has been accepted for publication in Applied Economics, published by Taylor and Francis.

\begin{abstract}
We study the relationship between differences in human capital and differences in product per worker of the federal entities of Mexico. We consider both quantity and quality of education in human capital formation, and use two methods for aggregating these two dimensions of education: a multiplicative and an additive model. Our measures of quality of education are constructed using the OECD's Program for International Student Assessment (PISA) math achievement test scores in the additive model, and using the differences in the returns to education of the states in the multiplicative model. Our results are consistent to different methodologies and data sources. We find that variations in human capital explain upwards of $40 \%$ of the variations in state GDP per worker. Our results indicate that Mexican states should place more emphasis both in the quantity as well as quality of schooling, in order to improve the living standards of their population.
\end{abstract}

JEL Codes: I25, I26, J24, R11, O54, O15

Keywords: Education; Human Capital; Mexico; Development Accounting

\footnotetext{
${ }^{1}$ Corresponding Author. 19000 Hubbard Drive, Dearborn, MI, 48126. Phone: (313) 583-6532. Email: mvalero@umich.edu.
} 


\section{Human Capital and Aggregate Income Differences in Mexico}

\section{Introduction}

This paper studies differences in human capital, and how these impact economic development of the federal entities in Mexico $^{2}$. Significant differences exist between the Mexican states, in terms of GDP per worker and GDP per hour worked, as well as in terms of human capital measured through the average years of schooling. In this paper we study the role of human capital as a possible source of income variations across the Mexican states. We refer to human capital as the one derived from schooling, and not as the one derived from work experience as in Bils and Klenow (2000). We first study the differences in human capital across states and then study whether differences in human capital across states can explain differences in GDP per worker and per hour worked.

International empirical studies suggest that differences in human capital (in terms of both quantity and quality of education) explain between 20 and 40 percent of the income differences of countries (Schoellman (2012), Hanushek and Woessmann (2012b)). Within a country, Hanushek, Ruhose and Woessmann (2017) find that between 20-30 percent of the variation in a state's GDP per capita can be explained by human capital differences in the case of the United States.

We consider both the quantity and the quality of human capital. We estimate human capital using two models. In the additive human capital formation model (Hanushek et al. 2017) the effects of years of schooling are added to its quality. We follow Hanushek et al. (2017) who utilize test scores to measure the quality of education, we use the PISA

\footnotetext{
${ }^{2}$ The federal entities include the 31 Mexican states in addition to Mexico City, we refer to these as the 32 Mexican states.
} 
Mathematics test scores as a measure of quality of schooling. In the multiplicative human capital formation model (Schoellman, 2012) years of schooling and quality of schooling are multiplied in the human capital production function. Following Schoellman (2012) we use the returns to education to approximate the quality of education, and like Card and Krueger (1992), we attribute the differences in returns to education to differences in quality of education in each of the Mexican states.

Mexico offers a perfect framework for studying the effects of quantity and quality of education in the formation of human capital and the participation of such in GDP per worker. Starting in 2003 and every three years since then, the PISA test is representative for each of the 32 Mexican states. An additional advantage of studying the case of Mexico is the composition of its GDP as compared to that of the United States. Hendricks (2002) finds total factor productivity differences cannot explain income differences between the U.S. and Mexico; hence differences between the two countries can be attributed to differences in either physical or human capital. Moreover, Hall and Jones (1999) suggest differences in human capital between Mexico and the U.S. are more important than differences in total factor productivity or in physical capital in terms of explaining the differences in output per worker of the two countries. This suggests that human capital is an important component in explaining income differences between Mexico and the United States.

The study of a single country also allows us to control for other factors that might affect income, hence we can estimate the effects of quality of schooling to income with greater certainty. Prior literature focuses on explaining the portion of income differences between countries that can be attributed to human capital. In these studies, the country where the individual is working might be different to the country where the education was received. By focusing on a single country, although the state where the education was received and the state 
where the individual works might be different, we are able to control for language and the culture of work, which one expects vary less within a country than internationally.

It is possible that in the case of Mexico human capital differences among the states are important in explaining income differences. Bils and Klenow (2000) model the effects of education on growth of GDP per capita, and find that schooling can explain less than one third of the schooling/growth cross-country relationship. They use parameters that assume decreasing returns to education, based on estimates by Psacharopoulos (1994) for several countries. Even though decreasing returns to education arises from the comparison between countries, this does not imply that each country has decreasing returns. By assuming diminishing returns, the importance of human capital in their model falls as more human capital is acquired, but growth in human capital can be important in explaining the schooling/growth relationship if there are no diminishing returns to education. Harberger and Guillermo-Peón (2012) find that in the case of Mexico the returns to education are not decreasing ${ }^{3}$, which would imply a stronger importance of schooling in explaining income differences in such case.

The study is timely and important in the case of Mexico. The current public education system was implemented in 1959 and had not had any significant changes since then. A proposal of an educational reform which looked to improve the quantity and quality of education in Mexico was presented in late 2012 by then president Enrique Peña Nieto, and was subsequently signed into law. However, in 2019 the educational reform was repealed. The quality of education has restrictions and differences at the state level in part due to the presence of large unions in the Mexican education sector, and to its management by the Mexican state.

\footnotetext{
${ }^{3}$ Patrinos, Ridao-Cano and Sakellarious (2006) find increasing returns to education for other countries also used in Psacharopulos's (1994) sample.
} 
Implicit in the educational reform proposal is the key assumption that such improvements in education will lead to a reduction in inequality and to greater economic development of the country, which will lead to an improvement in the lives of the country's constituents. There is some empirical evidence that a higher quality of education is related to higher wages in the case of Mexico. For instance, De Hoyos, Estrada and Vargas (2018) find a positive relationship between individual test scores and individual wages. Further, their findings indicate that higher test scores are associated with a higher probability of a student going to college. The study of human capital as a possible source of income differences among the Mexican states is thus significant for the country.

Our findings indicate that quality adjusted human capital explains upwards of $40 \%$ of the variations in income per worker of the states. This suggests that human capital is a significant component of income differences between the states in Mexico. As a comparison, Hanushek et al. (2017) find that between $20-30 \%$ of the variation in GDP per capita can be explained by human capital differences in the case of the United States. This study is important as there are no attempts in the literature to study the role of human capital as a source of income differences among the Mexican states. Further, only one other work studies the role of human capital as a source of income differences among states in a country (Hanushek et al., 2017 for the United States) where, as mentioned above, human capital seems to play a more important role in the case of Mexico. This study allows us to understand the role of human capital on the income of the people of the Mexican states, so that states can approve public policies effective in improving the income of their constituents.

The paper is structured as follows. In Section 2 we discuss the sample selection and data. Section 3 presents the analytical framework. Section 4 describes our measures of quality of education and in Section 5 we use those measures in addition to quantity of schooling in 
forming human capital. Section 6 presents the decomposition of variations in GDP that are accounted by differences in human capital. In section 7 we evaluate the robustness of the results. Section 8 discusses the results and Section 9 concludes.

\section{Sample selection and Data}

To estimate the working population and the hours worked in the labor market we use the 2010 Census (Censo de Poblacion y Vivienda, INEGI (2012)), the available data includes more than 11.9 million observations. Following Hanushek, Ruhose and Woessmann (2017) we select the working population between the ages of 20 and 65 who are not currently in school, leaving 3,304,715 observations, which, using expansion factors, represent 36.3 million workers. An alternative source of data is the National Employment Survey, ENOE (Encuesta Nacional de Ocupacion y Empleo). We corroborate the robustness of our results by using data from the 2016 ENOE in section 7 of this study. Taking the population between 20 and 65 years of age who are declared working and not currently in school leaves 136,197 ENOE observations representing 42.5 million workers.

To estimate state GDP per capita we use INEGI (2018). GDP per capita and GDP per hour worked are found by taking the state GDP and dividing by the selected working population and by the annual hours worked of the selected population, respectively, using either the 2010 Census or data from the third trimester of the 2016 ENOE. Table 1 shows GDP and years of schooling by state. The first two columns show GDP for 2010 and 2016, measured in millions of 2013 Mexican Pesos, the difference between them implies an annual growth rate of $2.89 \%$ on average. There are significant income differences among the 32 Mexican states. For instance, in 2016 the GDP per worker of Coahuila was 546,131 Mexican Pesos (MP), more than twice that of Michoacán, which was MP 261,831. Excluding the two states where the 
production of oil occurs in Mexico, Campeche and Tabasco, the second largest 2016 GDP per worker is Nuevo Leon at MP 642,637; which is more than three times higher than that of the second lowest which is Oaxaca at MP 195,321. The standard deviation in state incomes (excluding Campeche and Tabasco) is MP 146,715, which is higher than 39 percent of the national average. As a comparison, Hanushek et al. (2017) report the 2007 standard deviation in state incomes being around $15 \%$ of the national average in the case of the United States. The last two columns of Table 1 show the average years of schooling for the population in the work force in years 2010 and 2016. The difference in years of schooling between the top and bottom states is four years or five standard deviations. In comparison, the difference in years of schooling between the U.S. states with the maximum and minimum values is 3.6 standard deviations. Hence, in addition to significant income differences, we also observe significant differences in terms of years of schooling among the Mexican states.

\section{Analytical Framework}

To measure the contribution of human capital differences on income, we start with the production function $Y_{i}=K_{i}^{\alpha}\left(A_{i} H_{i}\right)^{1-\alpha}$, where $\mathrm{Y}$ is income, $\mathrm{K}$ is capital, $\mathrm{A}$ is total factor productivity, $\mathrm{H}$ is the amount of human capital-augmented labor used in production, and $\alpha$ refers to the proportion of income allocated to capital. This function allows the decomposition of the variations in product per worker into the different factors including human capital per worker $h$, as in Hall and Jones (1999) and Hanushek et al. (2017) among others. The production function on a per worker basis can be written as:

$$
\frac{Y}{L} \equiv y=h * A *\left(\frac{k}{y}\right)^{\alpha /(1-\alpha)}
$$


where $k \equiv \frac{K}{L}$ is the relation of capital to labor, and $y$ is income per worker, We can decompose the variance from log GDP per worker as in Klenow and Rodríguez-Clare (1997). This decomposition is presented by Hanushek, Schwerdt, Wiederhold and Woessmann (2015), and by Hanushek et al. (2017) as:

$$
\frac{\operatorname{cov}(\ln (y), \ln (h))}{\operatorname{var}(\ln (y))}+\frac{\operatorname{cov}\left(\ln (y), \ln \left(\left(\frac{k}{y}\right)^{\alpha /(1-\alpha)}\right)\right)}{\operatorname{var}(\ln (y))}+\frac{\operatorname{cov}(\ln (y), \ln (A))}{\operatorname{var}(\ln (y))}=1
$$

The first term refers to the variation in GDP per capita that can be attributed to human capital differences, which is the focus of this study. As a robustness check, following Hall and Jones (1999) we calculate the 5-state measure to account for the contribution of the difference in human capital to the difference in GDP per capita between the 5 richest and 5 poorest states. Additionally, we redo the measurement using the 3 richest and the 3 poorest states (3-state measure).

\subsection{Quality-adjusted Human Capital Measures}

In addition to using years of schooling to measure human capital, we also account for the quality of schooling across states. We consider two models that explain human capital formation as a function of the years of schooling, s, and the quality of schooling, Q. The first is an additive model, used by Bils and Klenow (2000) and Hanushek et al. (2017) among others; in the additive model the years of schooling measure is added to the quality of schooling measure in the human capital formation function. The second model is a multiplicative model, designed by Schoellman (2012), where years of schooling and quality of schooling are multiplied in the human capital production function. 


\subsubsection{Additive human capital formation}

In the additive model human capital formation is formulated as:

$$
h=e^{\theta s+\pi Q}
$$

The earnings gradients to years of schooling $\theta$, and quality of schooling $\pi$, establish the relationship of quantity and quality of schooling with human capital, $h$. There are two issues when determining the earnings gradients for years of schooling $(\theta)$ and quality of schooling $(\pi)$. The first is that the obtained values are useful in determining human capital and wages through the working life of individuals, and that they include individuals already in the workforce. The second is that the values of $\theta$ and $\pi$ have to be estimated simultaneously, otherwise $\theta$ could contain information about the quality of schooling and the cognitive abilities of the individual.

Our approach is to take the parameters of the earnings gradients from the current literature. The most common way of measuring the schooling gradient, $\theta$, is using Mincer regressions as in Card and Krueger (1992) and Shoellman (2012). However, the exclusion of cognitive skills measures confounds the estimation and hence the estimation is not appropriate in our context. We look for joint estimates of the earnings gradients for years of schooling and quality of schooling.

The quality factor $\pi$ is hard to estimate, as we look to estimate the effect of quality of schooling once the individuals are working. One possible way is to estimate returns early in an individual's career, possibly omitting differences across lifetime earnings. Lazear (2003) and Murnane, Willet, Duhaldeborde and Tyler (2000) observe individuals when they are in school and then again years later once they are in the labor force. They then relate differences in earnings to differences in education and abilities. They find that a one standard deviation in 
mathematics performance when in school leads to a 9-15\% increase in earnings. An alternative is to use estimates of lifetime earnings based on skills that are measured during the workers career. For instance, Hanushek et al. (2015) use data from the "Programme for the International Assessment of Adult Competencies" (PIAAC) find ranges of the earning returns to cognitive skills of 0.14 to 0.28 for the 23 countries in their sample. Their estimates for the United States are $8.1 \%$ return to school attainment and $13.8 \%$ return to cognitive skills. Hanushek and Woessmann's (2012a) estimate of $\pi$ is $14 \%$.

Facing the problem of no available joint estimates for Mexico we select the parameters that best fit our purpose given the limitation faced. Hanushek and Zhang (2009) estimate the value for individual literacy scores to school attainment and provide joint estimates for the parameters for 13 countries. In their baseline model, a classical Mincer equation with years of schooling, the estimate for returns to education is $11 \%$ for the United States and $11.3 \%$ for Chile (the only country in the sample from Latin America), with the returns in other countries being much lower (below 8.4\%). Given that our estimate of returns to education for Mexico using Mincer equations is $10.4 \%^{4}$, our approach is to use the values in the literature for the United States and use the parameters estimated for Chile as a robustness check. Once Hanushek and Zhang (2009) make adjustments cognitive skills, their estimation of $\theta$ is $8.0 \%$ for the United States and $8.9 \%$ for Chile, while their estimations of $\pi$ are $19.3 \%$ and $13.1 \%$ respectively. To make our study comparable to that of Hanushek et al. (2017) who study how differences in human capital can explain differences in income in the United States, we follow by using values of $8.1 \%$ for $\theta$ and $17 \%$ for $\pi$. As a robustness check, in Section 6 we vary the

\footnotetext{
${ }^{4}$ In unreported results. The regression specification is similar to that in equation (5), without the dummies for states j.
} 
value of $\pi$ to $13.1 \%$, which is the value estimated for Chile by Hanushek and Zhang (2009) and find similar results.

\subsubsection{Multiplicative human capital formation}

Schoellman (2012) defines human capital as:

$$
h\left(s_{j}, Q_{j}\right)=\exp \left[\left(s_{j} Q_{j}\right)^{\eta} / \eta\right]
$$

This equation interacts, for a migrant in the United States from country $\mathrm{j}$, the number of years of schooling $s_{j}$ with the quality of schooling $Q_{j}$, where the exponent $\eta$ moderates the interaction between both variables. Schooling quality and years of schooling are positively correlated as long as $0<\eta<1$. Because Schoellman (2012) associates the quality of schooling $\mathrm{Q}$ to the rate of return to education of migrants of country $\mathrm{j}$ in the United States, $s_{\mathrm{j}} Q_{\mathrm{j}}$ would be the percent increase in earnings from education for a person with years of schooling $s$ and quality $Q_{\mathrm{j}}$, like in the Mincer equation. We follow Schoellman's methodology for estimating quality adjusted schooling, applying it to each of the Mexican states in Section 5.

\section{Measures of Education Quality}

\subsection{Rates of Return to Education}

In the multiplicative human capital formation model, quality of schooling $Q_{j}$ (in equation 4) is estimated using returns to schooling by state, which we estimate as $\theta_{\mathrm{j}}$ through the following:

$$
\ln y_{i j k}=\alpha+\delta_{j}+\mu_{k}+\theta_{j} s_{i j k} \lambda_{j}+\gamma X_{i j k}+\varepsilon_{i j k}
$$


Where $i$ denotes individual, $j$ denotes the state of birth of the individual, and $k$ the state in which the individual was residing and working at the time of the 2010 census. The census does not provide data on where the individual received their education, therefore, the implicit assumption we make is that the individual received its education in their state of birth. For the regression, we select from our sample individuals who work 30 or more hours per week and earn at least $\$ 500$ pesos per month, who were born in a Mexican state and for which we have data on their years of schooling, leaving 2,244,341 observations. We regress, for 2010, the log of hourly income against years of schooling $\left(s_{i j k}\right)$ and a vector of controls $X_{i j k}$ that includes experience $($ experience $=$ age - education -6$)$ to the $1-4^{\text {th }}$ powers ${ }^{5}$, sex, and size of the city (under 15,000 habitants, 15,000 - 100,000 habitants, and more than 100,000 habitants), and if the individual is a migrant into the state or not. The vector $\delta_{\mathrm{j}}$ refers to the parameters of the state of birth fixed-effect and $\mu_{\mathrm{k}}$ to the vector of parameters representing the state of residence. Additionally, $\lambda_{\mathrm{j}}$ is a dummy variable for the population born in state $\mathrm{j}$, while $\theta_{\mathrm{j}}$ is the vector of parameters that represent the state-specific return to schooling. By controlling for the state of birth, we control for differences in education and in the learning habits of the state of birth, and by controlling for the state of residence we control for differences in technology that the states could have. For instance, Atkin (2016) finds that the manufacturer export sector in Mexico generated an abundance of low-ability work opportunities in exporting zones; the dummy variable would then control for these effects which occurred mainly in the north of Mexico. Under this specification, we allow the return to schooling to vary by state by interacting years of schooling $\mathrm{s}_{\mathrm{ijk}}$ with an indicator variable for the state of birth $\lambda_{\mathrm{j}}$ which is presumably where the individual received his education.

\footnotetext{
${ }^{5}$ We include experience to the $1-4^{\text {th }}$ powers following Murphy and Welch (1990), as justified in Hamlen and Hamlen (2012).
} 


\subsection{PISA Mathematics test achievement scores}

We use the OECD's Program for International Student Assessment (PISA) math achievement test scores as an additional measure of cognitive skills. Starting in 2003 the PISA test is representative for each of the Mexican states. Mathematics was the major subject of PISA in 2003 and 2012. Mexico scored well below the OECD average of 494 in the Mathematics portion of the 2012 PISA test (OECD 2014), with a score of 413, close to that of other Latin American countries and well below the score for the United States (481). According to the OECD, Mexico placed the equivalent of 2 years of schooling below the average OECD countries for same-grade students, and about 1.6 years of schooling lower than the United States.

We take the mathematics score on the PISA test for each state for the years 2003, 2006, 2009 and $2012^{6}$. We then calculate the average score across states by year, and normalize it with mean 500 and standard deviation of 100, to make it comparable to the data in Hanushek, Ruhose, and Woessmann (2017). We use the 2003-2012 state average as a measure of cognitive abilities of the working population ${ }^{7}$. We assume that test scores (and therefore quality) are stable over time, even though test scores can vary across successive tests ${ }^{8}$. We also assume that the average PISA test scores apply to the working population in 2010 and 2016.

\footnotetext{
${ }^{6}$ The exam was not administered in the state of Michoacán in 2003 and 2012, and it was not administered in Oaxaca or Sonora in 2012. We replace the 2006 value for the 2003 missing value and use the 2009 value for the 2012 missing values.

${ }^{7}$ We use the average score across time to avoid sample differences which occur each year the exam is administered, as these differences can be significant. For instance, in the state of Mexico the score was 399 in 2003, 433 in 2006, 415 in 2009 and 413 in 2012.

${ }^{8} \mathrm{We}$ do not have test results at the state level prior to 2003, and it is difficult to infer any trends from the PISA test results we do have. As an example, the overall PISA mathematics score for Mexico was 387 in 2000,385 in 2003, 405 in 2006, 418 in 2009, 413 in 2012 and 408 in 2015. One could erroneously infer an improving trend by looking at the 2000-2009 scores, which clearly is not the case once we see 2012-2015 scores.
} 
Table 2 shows the standardized PISA mathematics test scores for 2003 and for the average 2003, 2006, 2009 and 2012. The state with the highest average standardized score is Nuevo Leon, with 704, the lowest scoring state is Chiapas with 279. These two test scores are four standard deviations away from each other. As a comparison, Hanushek et al. (2017, online appendix Table 2) report the biggest difference in average standardized NAEP scores is between Minnesota and Missouri, 534.8 and 450.8 respectively, a difference of less than one standard deviation. These significant differences in quality of schooling across Mexico mirror the significant variations in GDP and in years of schooling discussed in Section 2.

We next adjust mean test scores for each state for interstate migration, the autoselection of interstate migration, and for international migration also considering its possible autoselection. We follow the methodology in Hanushek et al. (2017). The adjustments are summarized in Table 3. Adjusting for interstate migration, the mean PISA test score is unchanged while the standard deviation falls to 88. After adjusting the tests scores of state residents for their educational background, the mean falls indicating negative autoselection (individuals with less schooling). Finally, when we adjust for international migration the difference between the maximum and minimum state scores is at its lowest, with a difference in scores of 304 points, which represents more than 3 standard deviations ${ }^{9}$.

\section{Incorporating Schooling Quality into Human Capital}

We use two approaches to incorporate the measures of schooling quality into a human capital production function: the multiplicative and the additive model of human capital.

\footnotetext{
${ }^{9}$ The appendix (available from the authors) details the methodology used, and shows the adjustments of test scores, the returns to schooling and the human capital estimates using the additive and multiplicative models by state.
} 


\subsection{Estimating human capital using the multiplicative model.}

Once we have the estimates of quality of education for each state, we still need the parameter $\eta$ in order to account for quality in human capital formation through equation (4). We follow Schoellman's (2012) model and procedure for estimating $\eta^{10}$. The value for $\eta$ is derived from the estimation of the elasticity of years of schooling with respect to education quality, $\eta /(1-\eta)$, which we get through the following regression:

$$
\ln s_{j}=c+\frac{\eta}{1-\eta} \ln \left(Q_{j}\right)
$$

Where $s_{j}$ is years of schooling in state $j$; and quality of schooling $Q_{j}$ is estimated with returns to schooling $\theta_{\mathrm{j}}$ in this equation and in equation (4). From this estimation of elasticity, one can infer the value of $\eta$ to be used in equation (4). As part of this estimation, Schoellman (2012) recommends using standardized achievement test scores as instruments for the returns to schooling, as it is an additional measure of the quality of schooling which is unlikely to affect the years of schooling. Besides, one would not expect reverse causality of the test scores which are administered to 15-year-old students towards the years of schooling of the state. The instruments we use are the average adjusted PISA test scores and the distance from the state capital to the closest U.S. border city. We include distance to control for changing returns to education once trade was opened in Mexico. Open trade and hence the development of the export and maquiladora industry starting in 1986 could have had an impact in the returns to education for individuals in those industries, which are mainly located near the Mexican border with the U.S. Although Schoellman (2012) shows that a higher rate of return can affect years

\footnotetext{
${ }^{10}$ We follow equation (9) of Schoellman (2012).
} 
of schooling, Atkin (2016) finds that for those closer to the U.S. border years of educational attainment fell with the arrival of new export-manufacturing jobs.

Table 4 shows the estimates of the elasticity of school attainment and of $\eta$. The values of the elasticities are 0.24 in the OLS model and 0.25 in the model that uses instruments. Our elasticities are lower than those estimated by Schoellman (2012), which are as high as 1.36. To prove if the instruments are weak, Bound, Jaeger and Baker (1995) suggest the report of F and the partial R squared of the first stage estimates. We find a partial R squared of 0.62 and F higher than 22, which exceeds the value of 11.59 suggested by Stock, Wright, and Yogo (2002) to make the instruments reliable. Further, the Wald test of Stock and Yogo (2005) shows that at the $5 \%$ level we can have a rejection rate of no more than 10 , therefore the instruments are not weak. We can reject the null hypothesis that the independent variable is endogenous.

We use the estimate for $\eta$ and equation (4) to estimate human capital, the estimates show the top and bottom states are about 4 standard deviations away, indicating large dispersion in our human capital estimates among the Mexican states.

\subsection{Estimating human capital using the additive model.}

Hanushek et al. (2017), model human capital h(s, Q), as a function of years of schooling

and of cognitive abilities of the working population: $h=e^{\theta s+\pi Q}$. The value of s for each state is determined by the average years of schooling for the working population. Setting the value of $\pi$ at $17 \%$, we estimate human capital according to equation (3). We use the average adjusted PISA Math test scores as a measure of quality of schooling. We standardize the values with 
mean zero and variance of one, then further adjust so that our relative measure of quality (standardized difference in the PISA test score) has the minimum value of zero.

We estimate the Kendall Rank correlation for the estimates of human capital. We find a high correlation between human capital estimates in the case of the multiplicative model when using OLS or instruments (both generate the same order of the states for human capital). Considering the estimates with instruments, the additive and the multiplicative model order human capital in the states in the same way in more than $52 \%$ of the cases. Using Pearson correlation coefficients, the correlation between human capital in the additive and multiplicative model (with instruments) is greater than $70 \%$.

\section{Decomposing state variations in GDP into contributions accounted by differences in quality and quantity of human capital}

We next decompose the variation in product that can be attributed to differences in human capital. We exclude states whose industry structure makes GDP unlikely to be described well by a capital and labor production function, hence, we exclude those with abundant natural resources following Hall and Jones (1993) and Hanushek et al. (2017). There are two states where we cannot expect a direct relationship between human capital and product per worker, these are the states were the production of oil occurs in Mexico: Campeche and Tabasco. According to the Economic Census of 2008 (INEGI, 2015), 96\% of the value added in Campeche and $82 \%$ in Tabasco corresponds to the extraction of oil, thus one would expect a very weak relationship between GDP per worker and human capital in these two states, they are excluded from our sample at this point.

Table 5 shows the percentage of the variability in income attributed to human capital, estimated as in equation (2). In the additive model years of schooling explain $18 \%$ of the 
variation in GDP per worker, while cognitive abilities explain $31 \%$ using the adjusted PISA test scores. Therefore, human capital differences explain $49 \%$ of the differences in GDP. These estimates use values of $17 \%$ for $\pi$ and $8.1 \%$ for $\theta$. Alternatively, using $\pi=13.1 \%$, cognitive abilities explain $24 \%$ of the variation in income; and human capital explains $42 \%$ of the variations in GDP.

The bottom portion of the table refers to the multiplicative model. In this case human capital explains $70 \%$ of the variations in GDP per worker. This estimate is robust to using only adjusted test scores as an instrument.

Following Hall and Jones (1999) we also compare the relation between human capital in states with the highest and lowest GDP per hour worked in the last four columns of Table 5. The five-state and three-state measures provide similar results. Human capital differences explain between $54 \%$ and $77 \%$ of the differences between GDP per capita of the richest and poorest states when using the additive model, and between $65 \%$ and $86 \%$ when using the multiplicative model. Both models maintain their strong predictive power even for the case of largest and smallest states in terms of GDP per hour worked. Therefore, these estimates of the variation in income attributed to human capital do not fall once we use the five-state or threestate measure. A potential explanation is that we excluded the two outliers: Campeche and Tabasco. The results when we include Campeche and Tabasco will be discussed in Section 8 .

\section{Robustness Checks}

We now study if our estimates are robust to changes in a) the test period and data source; 2) using migrant workers only; and 3) using PISA 2003 test scores instead of the 20032012 averages. 


\subsection{Results for 2016}

Instead of using the 2010 Census, we could use the 2016 ENOE (Encuesta Nacional de Ocupacion y Empleo- National Survey of Occupation and Employment), which provides quarterly data on the working characteristics of the population. The more recent data comes at the cost of a much smaller sample. We use the third quarter from ENOE for 2016 (2016 is the latest year with GDP data by state). Imposing the same data restrictions as before our sample is 82,845 observations (compared to $2,244,341$ with the Census). The Census indicates place of birth, and in the case of international migration country of birth, allowing the adjustment of PISA test scores for international migration. This information is not available when using the ENOE.

The results using GDP per hour worked ${ }^{11}$ are shown in Table 6, Panel A shows the additive model and Panel B the multiplicative model. The percentage explained by human capital, which was $49 \%$ or more using the 2010 Census (Table 5), falls to $46 \%$. The proportion of the variation in the GDP per hour explained by human capital in the multiplicative model, which was $70 \%$ using the 2010 Census, is now reduced to $41 \%$ with the 2016 ENOE. A possible reason for the strong fall is that the national rates of return to education, which were estimated at $10.2 \%$ using the 2010 Census, are $7.2 \%$ using the 2016-III ENOE ${ }^{12}$.

Overall, our findings indicate that using ENOE 2016 the variations in the log of human capital still explain between $40 \%$ (multiplicative model) and $50 \%$ of the variations in log GDP.

\footnotetext{
11 The results using GDP per worker are qualitatively and quantitatively similar.

12 The ENOE sample is much smaller and income measurement more limited compared to the Census. Using hourly wages from the National Survey of Income and Expenditures of Households (ENIGH -Encuesta Nacional de Ingresos y Gastos de los Hogares de Mexico) we estimate national rates of return to education of $10 \%$ for both 2010 and 2016. Unfortunately, this survey is not representative at the state level.
} 


\subsection{Using only migrants in the multiplicative model}

A possible issue with the study of how human capital affects income is the problem of causality between income and education, that is, it is possible that the richest states will not only provide better education but also better returns to education. To control for this possibility, we separately study a subsample of individuals who are migrants into the state. To measure the returns to education of a particular state, we take all individuals born in that state (assuming they were educated there), but that later moved to a different state. Hence, we are taking individuals educated in one state and observing their incomes in other states. This way we break the problem of causality of income to education, as migrants are taking their education to a different state.

Other studies also use migrant earnings to study the importance of education (Hendricks, 2002) or its quality (Schoellman, 2012; Hanushek et al., 2017). They obtain data about migrants in their home country and observe the results on the productivity of the labor market in the United States. This is not without problems, as the U.S. market may not be the appropriate one. For instance, Schoellman (2012) estimates returns to education for migrants in the U.S. to use them in measurements of quality of education, but these returns can be very low, such as $1.8 \%$ for Mexico or $2.3 \%$ for Portugal, that they might not reflect the returns to education or quality of education of individuals in their home countries. Therefore, it is important to estimate returns to education in Mexico by using individuals educated and residing in Mexico, while breaking the causality from state income to education, even though biases in our estimations could arise given that the migrant population auto-selects (Borjas, 1987). When we consider the migrant population, the 2010 sample is 397,870 and the 2016 sample is 17,124 observations. Table 7 shows that variations in human capital explain $65 \%$ of 
the variations in GDP per hour worked in 2010 and around 55\% in 2016, when using migrant workers.

\subsection{Results using PISA 2003}

We re-estimate the results using the 2003 PISA test scores in lieu of the 2003-2012 average in the additive model. A 15 year old student who took the test in 2003 would be 22 years old in 2010, and 28 in 2016. In this case, we assume that the 2003 score is the appropriate one that applies to the working population in 2010 and 2016. Our results are robust to this correction. Table 8 shows that under such scenario differences in the quality and quantity of education explain between $42 \%$ (using the 2016 ENOE) and 46\% (using the 2010 Census) of the differences in the incomes (GDP per worker) of the states.

\section{Discussion of Results}

Hanushek et al. (2017, Table 2) find human capital explains $15 \%$ to $22.8 \%$ of the variations in GDP between the U.S states, after the sensitivity analysis these estimates are $18.1 \%$ to $31.5 \%$. In Schoellman (2012, Table 2), human capital explains between $19 \%$ and $36 \%$ of the variations in income in a cross-country study. Our results, however, show that in the case of the Mexican states the variability in GDP that can be explained by human capital is much larger, upwards of $40 \%$.

One possible explanation for the larger estimates for Mexico is that we excluded the two Mexican states characterized by their oil extraction activity: Campeche and Tabasco. The value of production in these states depends in large part on the price of oil and on the existence of oil reserves, and not on the amount of labor and capital, so empirically this would affect the 
value of total factor productivity. Table 9 shows results of our analysis with and without the inclusion of these two states. The variance in ln GDP per hour in 2010 is 0.9 when we exclude Campeche and Tabasco, 0.10 including Tabasco and 0.23 including both states. The variance in GDP increases more than 10-fold by including the two states, so variations in human capital are less able to explain this variance in GDP. By excluding them, we exclude a source of the variations in total factor productivity and the variance is better explained directly by the inputs. In particular, following the additive model of Hanushek et al. (2017) human capital explains $49 \%$ of the variations in income in 2010 excluding the two states but only $7 \%$ if they are included. Similarly, following Shoellman's (2012) multiplicative model human capital explains $70 \%$ of the variations in income in 2010 when the two states are excluded but only $28 \%$ when they are included.

Another possible explanation for why the variations in human capital explain such a large fraction of the variations in GDP among the Mexican states is that capital $(\mathrm{K})$ is not good at explaining such variations in income. In particular, the variance in GDP per worker can be attributed to three components as indicated in equation (2), the portions due to variations in human capital, to variations in capital, and to variations in total factor productivity. There is no data available for capital by state, but there is data on the National Accounts on the gross fixed capital formation by state between 2003 and 2017 (INEGI, 2019). Using this data and the method of perpetual inventories, we find a negative covariance between income and capital (the second term in equation 2) for both 2010 and 2016. Therefore, there is room for human capital to explain the variations in income of the Mexican States ${ }^{13}$.

\footnotetext{
${ }^{13} \mathrm{We}$ follow the program in Amadou (2011) and use a depreciation rate of $5 \%$ and values for $\alpha$ of $1 / 3,1 / 2$ and 2/3 for both 2010 and 2016, and all give estimates of a negative covariance term. Given the short time series available, these results should be interpreted with caution.
} 


\section{Conclusions}

Our study shows that differences in schooling, both in terms of quantity and quality, explain upwards of $40 \%$ of the changes in GDP per worker. This result is robust to taking the five states with higher and lower GDP per hour worked, and also to taking the top and bottom three states. We used two methodologies to measure quality adjusted human capital, in the additive model quantity and quality of schooling are added in the human capital production function, and quality of schooling is measured using the achievement scores of the PISA mathematics test. The variations in human capital explain between to $40-50 \%$ of the variations in GDP per worker. The result is robust to using a different survey and year for data, the 2016 ENOE in lieu of the 2010 census, and to using the 2003 PISA test results instead of the 20032006-2009-2012 average.

In the multiplicative model human capital explains $70 \%$ of the variations in GDP per hour worked. The result is not driven by a problem of causality from GDP to education, as the results still hold when we take individuals who were born and probably educated in a state different from their current state of work. When we use the 2016 ENOE, the estimates fall to the same range as the additive model, $40-50 \%$. The reason for the fall is that the rates of return to education estimated are much lower when using 2016 ENOE compared to when we use the 2010 Census.

Of particular importance is which states are included. We exclude Campeche and Tabasco as they are oil producing states where GDP is not reflective of the amount of labor and capital of the state. When including these states variations in human capital explain only 
$7 \%$ of the variations in GDP per hour in the case of the additive model and $28 \%$ in the case of the multiplicative model.

A variation of the model in Blis and Klenow (2000) would show that the effects of education on growth of GDP per capita could be important in cases where countries do not exhibit diminishing returns to education, such as the case of Mexico. Our results show that human capital differences among the states are important in explaining income differences in Mexico. 


\section{References}

Amadou, D. I. (2011). STOCKCAPIT: Stata module to calculate physical capital stock by the perpetual-inventory method. Statistical Software Components S457270, Boston College Working Papers in Economics.

Atkin, D. (2016). Endogenous skill acquisition and export manufacturing in Mexico. American Economic Review, 106, 2046-2085.

Bils, M., \& Klenow, P. J. (2000). Does Schooling Cause Growth? The American Economic Review, 90, 1160-1183.

Borjas, G. (1987). Self-Selection and the Earnings of Immigrants. The American Economic Review, 77, 531-553.

Bound, J., Jaeger, D. A., \& Baker, R. M. (1995). Problems with instrumental variables estimation when the correlation between the instruments and the endogenous explanatory variable is weak. Journal of the American Statistical Association, 90(430), 443-450.

Card, D., \& Krueger, A. (1992). Does school quality matter? Returns to education and the characteristics of public schools in the United States. The Journal of Political Economy, 100, 1-40.

De Hoyos, R.; Estrada, R.; and Vargas, M. (2018). Predicting Individual Wellbeing Through Test Scores: Evidence from a National Assessment in Mexico. Policy Research Working Paper;No. 8459. Washington, D.C.: World Bank Group.

Elizondo Mayer-Serra, C. E. (2009). Perverse equilibria: unsuitable but durable institutions. In S. Levy \& M. Walton (Eds.), No growth without equity? Inequality, interests, and competition in Mexico (pp. 157-202). New York: Palgrave Macmillan and the World Bank.

Harberger, A. C., \& Guillermo-Peón, S. (2012). Estimating private returns to education in Mexico. Latin American Journal of Economics, 49, 1-35.

Hall, R. E., \& Jones, C. I. (1999). Why Do Some Countries Produce So Much More Output Per Worker Than Others? The Quarterly Journal of Economics, 114, 83-116. 
Hamlen, S. S., \& Hamlen, W. A. (2012). The inconsistency of the quadratic Mincer equation: a proof. Theoretical Economics Letters, 2(02), 115.

Hanushek, E. A., Ruhose, J., \& Woessmann, L. (2017). Knowledge Capital and Aggregate Income Differences: Development Accounting for US States. American Economic Journal: Macroeconomics, 9(4), 184-224.

Hanushek, E. A., Schwerdt, G., Wiederhold, S., \& Woessmann, L. (2015). Returns to Skills around the World: Evidence from PIAAC. European Economic Review, 73, 103-130.

Hanushek, E. A., \& Woessmann, L. (2012a). Do better schools lead to more growth? Cognitive skills, economic outcomes, and causation. Journal of Economic Growth, 17, 267-321

Hanushek, E. A., \& Woessmann, L. (2012b). Schooling, educational achievement, and the Latin American growth puzzle. Journal of Development Economics, 99, 497-512.

Hanushek, E. A., \& Zhang, L. (2009). Quality-consistent estimates of international schooling and skill gradients. Journal of Human Capital, 3, 107-143.

Hendricks, Lutz. 2002. "How Important Is Human Capital for Development? Evidence from Immigrant Earnings." The American Economic Review, 92, 198-219.

INEGI. (2012). Censo de Población y Vivienda 2010. Retrieved July 13, 2018, from Instituto Nacional de Estadística y Geografía http://www.beta.inegi.org.mx/proyectos/ccpv/2010/

INEGI.(2015). "Minimonografías por entidad federativa, censos económicos 2009". .Retrieved from http://www.inegi.org.mx/est/contenidos/espanol/proyectos/censos/ce2009/minimonog $\underline{\text { rafias.asp }}$

INEGI. (2018). Producto interno bruto por entidad federativa. Base 2013. From Instituto Nacional de Estadística y Geografía. https://www.inegi.org.mx/sistemas/bie/?idserpadre=10200070\#D10200070

INEGI. (2019). Cuentas Nacionales - Gobiernos estatales, formación bruta de capital fijo, base 2013. Retrieved 05/31/2019, from Instituto Nacional de Estadística y Geografía https://www.inegi.org.mx/sistemas/bie/ 
Klenow, P., \& Rodriguez-Clare, A. (1997). The neoclassical revival in growth economics: Has it gone too far? NBER Macroeconomics Annual 1997, Volume 12 (pp. 73-114): MIT Press.

Lazear, E. P. (2003). Teacher incentives. Swedish Economic Policy Review, 10, 179-214.

Murnane, R. J., Willet, J. B., Duhaldeborde, Y., \& Tyler, J. H. (2000). How important are the cognitive skills of teenagers in predicting subsequent earnings? Journal of Policy Analysis and Management, 19, 547-568.

Murphy, K. M., \& Welch, F. (1990). Empirical age-earnings profiles. Journal of Labor Economics, 8(2), 202-229.

OECD (2014). PISA 2012 Results: What Students Know and Can Do - Student Performance in Mathematics, Reading and Science (Volume I, Revised edition, February 2014); PISA, OECD Publishing.

Patrinos, Harry A; Cristóbal Ridao-Cano and Chris Sakellariou. 2006. Estimating the Returns to Education: Accounting for Heterogeneity in Ability. Policy Research Working Paper; No. 4040. World Bank, Washington, DC.

Psacharopoulos, George. 1994. "Returns to Investment in Education: A Global Update." World Development, 22, 1325-1343.

Schoellman, T. (2012). "Education quality and development accounting." The Review of Economic Studies, 79, 388-417.

Stock, J. H., Wright, J. H., \& Yogo, M. (2002). A survey of weak instruments and weak identification in generalized method of moments. Journal of Business \& Economic Statistics, 20, 518-529.

Stock, J. H., \& Yogo, M. (2005). Testing for weak instruments in linear IV regression. In D. W. K. Andrews (Ed.), Identification and inference for econometric models: Essays in honor of Thomas Rothenberg (pp. 80 - 108). New York: Cambridge University Press. 
Table 1. GDP and years of schooling for the Mexican states.

\begin{tabular}{|c|c|c|c|c|c|c|c|c|}
\hline & 2010 GDP & 2016 GDP & $\begin{array}{l}2010 \text { GDP } \\
\text { per worker }\end{array}$ & $\begin{array}{l}2016 \text { GDP } \\
\text { per worker }\end{array}$ & $\begin{array}{c}2010 \text { GDP } \\
\text { per hour } \\
\text { worked }\end{array}$ & $\begin{array}{c}2016 \text { GDP } \\
\text { per hour } \\
\text { worked }\end{array}$ & $\begin{array}{c}2010 \\
\text { Years of } \\
\text { schooling }\end{array}$ & $\begin{array}{c}2016 \\
\text { Years of } \\
\text { schooling }\end{array}$ \\
\hline Aguascalientes & 152,205 & 216,703 & 401,990 & 471,061 & 164 & 190 & 10.0 & 10.5 \\
\hline Baja California & 428,163 & 524,405 & 376,012 & 403,685 & 156 & 173 & 9.7 & 10.1 \\
\hline Baja California Sur & 110,656 & 133,147 & 441,152 & 450,063 & 186 & 193 & 10.3 & 10.6 \\
\hline Campeche & 753,969 & 600,771 & $2,767,822$ & $1,836,844$ & 1,104 & 780 & 9.4 & 10.0 \\
\hline Coahuila & 489,952 & 583,873 & 541,627 & 546,131 & 220 & 232 & 10.2 & 10.5 \\
\hline Colima & 81,992 & 101,336 & 340,332 & 364,120 & 139 & 158 & 9.7 & 10.1 \\
\hline Chiapas & 270,989 & 288,692 & 207,848 & 178,923 & 89 & 81 & 7.3 & 7.7 \\
\hline Chihuahua & 417,796 & 539,144 & 378,700 & 390,336 & 160 & 166 & 9.4 & 10.0 \\
\hline Ciudad de Mexico & $2,446,910$ & $2,974,071$ & 716,881 & 843,660 & 292 & 358 & 11.3 & 11.7 \\
\hline Durango & 169,268 & 202,998 & 363,232 & 341,422 & 150 & 148 & 9.5 & 9.9 \\
\hline Guanajuato & 517,169 & 691,613 & 313,169 & 356,276 & 127 & 145 & 8.6 & 9.2 \\
\hline Guerrero & 211,891 & 238,468 & 226,295 & 210,202 & 94 & 92 & 8.3 & 8.5 \\
\hline Hidalgo & 206,304 & 264,242 & 253,440 & 261,985 & 106 & 113 & 9.0 & 9.1 \\
\hline Jalisco & 925,372 & $1,161,406$ & 377,290 & 412,538 & 156 & 185 & 9.5 & 10.1 \\
\hline México & $1,226,814$ & $1,478,587$ & 238,680 & 241,531 & 93 & 100 & 9.6 & 10.0 \\
\hline Michoacán & 329,767 & 406,185 & 260,443 & 261,831 & 110 & 123 & 8.2 & 8.5 \\
\hline Morelos & 174,984 & 191,797 & 286,990 & 278,932 & 117 & 119 & 9.8 & 9.9 \\
\hline Nayarit & 97,786 & 119,106 & 281,850 & 277,000 & 119 & 125 & 9.5 & 9.9 \\
\hline Nuevo León & $1,025,184$ & $1,228,744$ & 627,538 & 642,637 & 252 & 272 & 10.5 & 10.9 \\
\hline Oaxaca & 228,089 & 257,146 & 218,661 & 195,321 & 92 & 86 & 7.9 & 8.1 \\
\hline Puebla & 469,968 & 557,877 & 270,890 & 254,118 & 111 & 114 & 8.7 & 9.0 \\
\hline Querétaro & 287,403 & 385,622 & 464,254 & 581,925 & 195 & 241 & 9.9 & 10.3 \\
\hline Quintana Roo & 195,149 & 262,760 & 386,601 & 393,597 & 150 & 161 & 9.7 & 10.2 \\
\hline San Luis Potosí & 269,397 & 346,378 & 355,697 & 379,290 & 151 & 168 & 9.4 & 9.8 \\
\hline Sinaloa & 312,655 & 381,109 & 366,133 & 385,254 & 150 & 172 & 10.0 & 10.4 \\
\hline Sonora & 431,502 & 570,174 & 489,434 & 547,739 & 202 & 234 & 10.1 & 10.7 \\
\hline Tabasco & 525,012 & 523,613 & 764,475 & 692,312 & 305 & 291 & 9.7 & 9.9 \\
\hline Tamaulipas & 448,215 & 489,100 & 414,387 & 388,932 & 168 & 172 & 10.0 & 10.2 \\
\hline Tlaxcala & 88,810 & 97,665 & 234,560 & 218,018 & 97 & 93 & 9.5 & 9.9 \\
\hline Veracruz & 718,149 & 811,543 & 307,670 & 319,747 & 124 & 140 & 8.6 & 8.8 \\
\hline Yucatán & 196,150 & 242,005 & 295,846 & 294,169 & 121 & 131 & 9.0 & 9.3 \\
\hline Zacatecas & 144,731 & 157,898 & 363,048 & 324,869 & 153 & 141 & 8.9 & 9.4 \\
\hline All Mexico & $14,352,401$ & $17,028,177$ & 395,809 & 400,283 & 162 & 172 & 9.4 & 9.8 \\
\hline Mean & & & 447,905 & 429,515 & 183 & 184 & 9.4 & 9.8 \\
\hline Std. Dev. & & & 437,608 & 294,048 & 174 & 124 & 0.8 & 0.8 \\
\hline
\end{tabular}

* GDP is measured in millions of 2013 pesos. GDP per hour worked and per worker are in constant 2013 pesos. 
Table 2. PISA Mathematics test scores for the Mexican states.

\begin{tabular}{|c|c|c|}
\hline & $\begin{array}{c}\text { PISA test } \\
\text { scores 2003 }\end{array}$ & $\begin{array}{l}\text { PISA test scores } \\
\text { average 2003- } \\
\text { 2006-2009-2012 }\end{array}$ \\
\hline Aguascalientes & 639 & 634 \\
\hline Baja California & 482 & 487 \\
\hline Baja California Sur & 518 & 447 \\
\hline Campeche & 364 & 370 \\
\hline Coahuila & 541 & 544 \\
\hline Colima & 555 & 544 \\
\hline Chiapas & 242 & 279 \\
\hline Chihuahua & 544 & 580 \\
\hline Ciudad de Mexico & 577 & 653 \\
\hline Durango & 586 & 527 \\
\hline Guanajuato & 550 & 546 \\
\hline Guerrero & 286 & 263 \\
\hline Hidalgo & 556 & 537 \\
\hline Jalisco & 637 & 618 \\
\hline México & 499 & 564 \\
\hline Michoacán & 538 & 506 \\
\hline Morelos & 608 & 575 \\
\hline Nayarit & 514 & 491 \\
\hline Nuevo León & 703 & 704 \\
\hline Oaxaca & 486 & 432 \\
\hline Puebla & 518 & 526 \\
\hline Querétaro & 538 & 605 \\
\hline Quintana Roo & 451 & 458 \\
\hline San Luis Potosí & 498 & 480 \\
\hline Sinaloa & 491 & 513 \\
\hline Sonora & 492 & 492 \\
\hline Tabasco & 284 & 288 \\
\hline Tamaulipas & 511 & 488 \\
\hline Tlaxcala & 444 & 440 \\
\hline Veracruz & 398 & 448 \\
\hline Yucatán & 429 & 444 \\
\hline Zacatecas & 520 & 519 \\
\hline Mean & 500 & 500 \\
\hline Std. Dev. & 100 & 100 \\
\hline Max-Min & 461 & 425 \\
\hline
\end{tabular}


Table 3. Adjustment of PISA test scores for interstate migration, autoselection of interstate migration, and international migration.

\begin{tabular}{|c|c|c|c|c|c|}
\hline Variable & Obs & Mean & $\begin{array}{l}\text { Std. } \\
\text { Dev }\end{array}$ & Min & Max \\
\hline Average 2003-2012 standardized & 32 & 500 & 100 & 263 & 704 \\
\hline Average + interstate migrants & 32 & 500 & 88 & 286 & 647 \\
\hline $\begin{array}{l}\text { Average }+ \text { interstate migrants }+ \text { adjustment by } \\
\text { educational category }\end{array}$ & 32 & 496 & 78 & 296 & 602 \\
\hline $\begin{array}{l}\text { Average }+ \text { interstate migrants }+ \text { adjustment by } \\
\text { educational category }+ \text { international migrants }\end{array}$ & 32 & 497 & 78 & 298 & 602 \\
\hline
\end{tabular}


Table 4. Elasticity of years of schooling with respect to quality of schooling, using 2010 Census data.

\begin{tabular}{|c|c|c|c|c|}
\hline & \multicolumn{2}{|c|}{ OLS } & \multicolumn{2}{|c|}{ Instruments } \\
\hline & Elasticity & Implied $\eta$ & Elasticity & Implied $\eta$ \\
\hline Coefficient & $0.239 * * *$ & 0.194 & $0.247 * * *$ & 0.198 \\
\hline Std. Dev. & $(.051)$ & & $(.063)$ & \\
\hline
\end{tabular}


Table 5. Percentage of variability of income attributed to human capital, using 2010 Census data.

\begin{tabular}{|c|c|c|c|c|c|c|c|c|}
\hline \multicolumn{2}{|c|}{ Share Q quality } & \multirow[t]{2}{*}{$\begin{array}{l}\text { Years of } \\
\text { schooling }\end{array}$} & \multicolumn{2}{|c|}{$\begin{array}{c}\text { Total sum of } \\
\text { quality and } \\
\text { quantity } Q \text { and } S\end{array}$} & \multicolumn{2}{|c|}{$\begin{array}{c}\text { Top and bottom } 5 \\
\text { states } \\
\text { Q and } S\end{array}$} & \multicolumn{2}{|c|}{$\begin{array}{c}\text { Top and bottom } 3 \\
\text { states } \\
Q \text { and } S\end{array}$} \\
\hline $\begin{array}{c}\text { ln GDP } \\
\text { per } \\
\text { worker }\end{array}$ & $\begin{array}{l}\text { ln GDP } \\
\text { per hour }\end{array}$ & & $\begin{array}{c}\text { ln GDP } \\
\text { per } \\
\text { worker }\end{array}$ & $\begin{array}{l}\text { ln GDP } \\
\text { per hour }\end{array}$ & $\begin{array}{c}\text { ln GDP } \\
\text { per } \\
\text { worker }\end{array}$ & $\begin{array}{c}\text { ln } G D P \\
\text { per hour }\end{array}$ & $\begin{array}{c}\text { ln GDP } \\
\text { per } \\
\text { worker }\end{array}$ & $\begin{array}{l}\text { ln } G D P \\
\text { per hour }\end{array}$ \\
\hline
\end{tabular}

Additive model

\begin{tabular}{|c|c|c|c|c|c|c|c|c|c|}
\hline $\begin{array}{l}\text { Average 2003-2012 } \\
\text { standardized }\end{array}$ & 0.35 & 0.34 & 0.18 & 0.53 & 0.52 & 0.57 & 0.58 & 0.75 & 0.77 \\
\hline $\begin{array}{l}\text { Average } \\
+ \text { interstate migrants }\end{array}$ & 0.33 & 0.33 & 0.18 & 0.51 & 0.51 & 0.56 & 0.56 & 0.74 & 0.77 \\
\hline $\begin{array}{l}\text { Average } \\
+ \text { interstate migrants } \\
+ \text { adjustment by educational } \\
\text { category }\end{array}$ & 0.31 & 0.31 & 0.18 & 0.49 & 0.49 & 0.54 & 0.55 & 0.72 & 0.75 \\
\hline $\begin{array}{l}\text { Average } \\
+ \text { interstate migrants } \\
+ \text { adjustment by educational } \\
\text { category + international } \\
\text { migrants }\end{array}$ & 0.31 & 0.31 & 0.18 & 0.49 & 0.49 & 0.54 & 0.55 & 0.73 & 0.75 \\
\hline
\end{tabular}

\section{Multiplicative model}

OLS

0.70

0.70

0.65

0.65

0.83

0.86

Instruments

0.70

0.70

0.65

0.65

0.83

0.86 
Table 6. Percentage of variability of income attributed to human capital using 2016 ENOE.

Panel A. Results additive model

\begin{tabular}{lccc}
\hline & $\begin{array}{c}\text { Share Q } \\
\text { quality }\end{array}$ & $\begin{array}{c}\text { Years of } \\
\text { schooling }\end{array}$ & $\begin{array}{c}\text { Total sum of } \\
\text { quality and } \\
\text { quantity Q } \\
\text { and S }\end{array}$ \\
\cline { 2 - 4 } & 0.32 & 0.17 & 0.49 \\
$\begin{array}{l}\text { Average 2003-2012 standardized } \\
\begin{array}{l}\text { Average } \\
\text { + interstate migrants }\end{array}\end{array}$ & 0.31 & 0.17 & 0.48 \\
$\begin{array}{l}\text { Average } \\
\text { + interstate migrants } \\
\text { + adjustment by educational category }\end{array}$ & 0.29 & 0.17 & \\
$\begin{array}{l}\text { Average } \\
\text { + interstate migrants } \\
\text { + adjustment by educational category } \\
\text { + international migrants }\end{array}$ & $\mathrm{n} / \mathrm{a}$ & 0.17 & \\
\hline
\end{tabular}

Panel B. Results multiplicative model

\begin{tabular}{|c|c|c|c|c|c|}
\hline \multirow[b]{3}{*}{ Coefficient } & \multicolumn{2}{|c|}{ OLS } & \multicolumn{2}{|c|}{ Instruments } & \multirow[b]{2}{*}{$\mathrm{F}$} \\
\hline & Elasticity & $\eta$ & Elasticity & $\eta$ & \\
\hline & $0.178^{* *}$ & 0.151 & $0.467 * *$ & 0.318 & 3.196 \\
\hline Std. Dev & $(0.077)$ & & $(0.209)$ & & \\
\hline
\end{tabular}

Variation explained by

$\begin{array}{lll}\text { human capital } & 0.41 & 0.39\end{array}$

$*, * *$, and $* * *$ refer to significance of the coefficients at the $10 \%, 5 \%$ and $1 \%$ levels, respectively. 
Table 7. Results of multiplicative model for GDP per hour for years 2010 and 2016 using only migrants.

\begin{tabular}{|c|c|c|c|c|c|c|c|c|c|c|}
\hline & \multicolumn{5}{|c|}{2010} & \multicolumn{5}{|c|}{2016} \\
\hline & \multicolumn{2}{|c|}{ OLS } & \multicolumn{2}{|c|}{ Instruments } & \multirow[b]{2}{*}{$\mathrm{F}$} & \multicolumn{2}{|c|}{ OLS } & \multicolumn{2}{|c|}{ Instruments } & \multirow[b]{2}{*}{$\mathrm{F}$} \\
\hline & Elasticity & $\eta$ & Elasticity & $\eta$ & & Elasticity & $\eta$ & Elasticity & $\eta$ & \\
\hline Coefficient & $0.301 * * *$ & 0.232 & $0.332 * * *$ & 0.249 & 10.104 & $0.203 * * *$ & 0.167 & $0.240 * * *$ & $\begin{array}{c}0.19 \\
3\end{array}$ & $\begin{array}{c}10.05 \\
6\end{array}$ \\
\hline Std. Dev & $(0.050)$ & & $(0.074)$ & & & $(0.045)$ & & $(0.067)$ & & \\
\hline $\begin{array}{l}\text { Variation explained } \\
\text { by human capital }\end{array}$ & 0.6 & & 0.65 & & & 0.55 & & 0.55 & & \\
\hline
\end{tabular}


Table 8. Variability of income attributed to human capital using PISA 2003

\begin{tabular}{|c|c|c|c|c|c|c|}
\hline & \multicolumn{3}{|c|}{ Results for 2010- using PISA 2003} & \multicolumn{3}{|c|}{ Results for 2016- using PISA 2003} \\
\hline & $\begin{array}{l}\text { Share } \\
\text { Q } \\
\text { quality }\end{array}$ & $\begin{array}{c}\text { Years of } \\
\text { schooling }\end{array}$ & $\begin{array}{c}\text { Total } \\
\text { sum of } \\
\text { quality } \\
\text { and } \\
\text { quantity } \\
Q \text { and } S \\
\end{array}$ & $\begin{array}{l}\text { Share } \\
\text { Q } \\
\text { quality }\end{array}$ & $\begin{array}{c}\text { Years of } \\
\text { schooling }\end{array}$ & $\begin{array}{c}\text { Total sum } \\
\text { of quality } \\
\text { and } \\
\text { quantity } Q \\
\text { and } S\end{array}$ \\
\hline \multicolumn{7}{|l|}{ Additive model } \\
\hline PISA 2003 standardized & 0.31 & 0.18 & 0.49 & 0.27 & 0.17 & 0.44 \\
\hline $\begin{array}{l}\text { Average } \\
+ \text { interstate migrants }\end{array}$ & 0.30 & 0.18 & 0.47 & 0.27 & 0.17 & 0.43 \\
\hline $\begin{array}{l}\text { Average } \\
+ \text { interstate migrants } \\
+ \text { adjustment by educational category }\end{array}$ & 0.28 & 0.18 & 0.46 & 0.25 & 0.17 & 0.42 \\
\hline $\begin{array}{l}\text { Average } \\
+ \text { interstate migrants } \\
+ \text { adjustment by educational category } \\
+ \text { international migrants }\end{array}$ & 0.28 & 0.18 & 0.46 & $\mathrm{n} / \mathrm{a}$ & 0.17 & $\mathrm{n} / \mathrm{a}$ \\
\hline
\end{tabular}


Table 9. Variability of income attributed to human capital when including Campeche and Tabasco

\begin{tabular}{|c|c|c|c|c|c|c|}
\hline & \multicolumn{2}{|c|}{ Baseline (30 states) } & \multicolumn{2}{|c|}{$\begin{array}{l}\text { Baseline } \\
\quad+\text { Tabasco }\end{array}$} & \multicolumn{2}{|c|}{$\begin{array}{l}\text { Baseline } \\
\quad+\text { Tabasco } \\
\quad+\text { Campeche }\end{array}$} \\
\hline & 2010 & 2016 & 2010 & 2016 & 2010 & 2016 \\
\hline Number of states & 30 & 30 & 31 & 31 & 32 & 32 \\
\hline Var ln GDP per hour & 0.09 & 0.12 & 0.10 & 0.13 & 0.23 & 0.21 \\
\hline Quantity of schooling & 0.18 & 0.17 & 0.15 & 0.10 & 0.07 & 0.07 \\
\hline \multicolumn{7}{|l|}{ Additive model } \\
\hline Quality of schooling & 0.31 & 0.29 & 0.16 & 0.19 & 0.00 & 0.05 \\
\hline Total (quality + quantity) & 0.49 & 0.46 & 0.31 & 0.29 & 0.07 & 0.12 \\
\hline \multicolumn{7}{|l|}{ Multiplicative model } \\
\hline OLS & 0.70 & 0.41 & 0.57 & 0.34 & 0.28 & 0.23 \\
\hline
\end{tabular}




\section{Appendix A: Methodology for adjusting test scores for migration between states, autoselection of migrants, and international migration.}

We adjust the PISA test scores of each state following Hanushek et al. (2017). First, we adjust test scores for interstate migration and for the autoselection of interstate migration, and then we adjust test scores for international migration and its autoselection.

\section{$\underline{\text { Interstate Migration }}$}

In our base model, we assign each individual the PISA test score of their state of residence. To correct test scores by interstate migration, we distinguish between an individual's state of birth and their state of residence. If an individual resides in a state other than their birth state, we assume the individual went to school in their birth state and therefore assign the birth-state PISA test scores to the individual. First, for each state, we group residents according to their birth state. For instance, in Aguascalientes $70.8 \%$ of the were born there, while $7 \%$ were born in Mexico City, $6 \%$ in Zacatecas, 5\% in Jalisco and so on for each of the 32 states. We also form a category of state residents who were born outside Mexico (international migrants). To adjust the state average test score for interstate migrants in the case of Aguascalientes, we would then multiply the PISA test score of Aguascalientes by 70.8\%, and to this add 7\% of the score of Mexico City, and so on. In the case of international migrants, we assign them the average score of their state of residence initially. We correct for international migration as the last step of these adjustments.

Table 1A shows the 2003-2012 average Mathematics PISA test scores by state, standardized with mean 500 and standard deviation 100. After correcting for interstate migration (columns 3 and 4) the average score is still 500 while the standard deviation falls to 88 . 


\section{$\underline{\text { Correction for migrant autoselection bias }}$}

To correct for migrant interstate autoselection, we separate workers into two groups, those with up to 12 years of schooling and those with 13 years or more, with the objective of identifying individuals with access to higher education. For instance, $70.8 \%$ of the residents of Aguascalientes were born in the state, this group can be split into $55.8 \%$ which have up to 12 years of schooling and $15 \%$ with 13 years or more. Then, for each state we subdivide the individual PISA test scores according to whether at least one of the test taker's parents has some higher education. We then make the assumption, as in Hanushek et al. (2017), that we can assign individuals with higher education the PISA test score of children whose parents have higher education, and vice versa for individuals without higher education. We then adjust PISA test scores by weighing them according to interstate migration, but adjusting separately for residents with higher education and those without. As a result of this adjustment, the average 2010 PISA score falls to 496 and the standard deviation falls to 78 (column 5 in Table 1A).

Correction for international migration.

Our sample (10\% of the Population Census) contains 9613 working foreigners from 92 countries, out of $3,304,715$ total workers, hence less than $0.3 \%$ of the working population are international immigrants. To obtain test scores for these migrants, we use OECD (2004, Table 2.3c) PISA mathematics test scores, where we take the mean, standard deviation, and 75 and 90

percentiles approximating the methodology of Hanushek et al. (2017). For the countries for which 
we do not have PISA scores, we approximate the scores using countries that are similar or geographically close..$^{14}$

To adjust for the selectivity of international migration in Mexico we follow Hanushek et al. (2017) who show that in the case of the U.S. such selectivity is significant. We start by computing the selectivity parameter $\mathrm{p}$ for each country, which indicates the percentile of the home country distribution from which the average immigrant comes, from educational degrees primary (pri), secondary (sec) or tertiary (ter). The equation that Hanushek et al. (2017) use to calculate the selectivity parameter is the following:

$$
p=s_{M X}^{p r i} * \frac{1}{2} s_{\mathrm{hom} e}^{p r i}+s_{M X}^{\mathrm{sec}} *\left(s_{\mathrm{hom} e}^{p r i}+\frac{1}{2} s_{\mathrm{hom} e}^{\mathrm{sec}}\right)+s_{M X}^{\text {ter }} *\left(s_{\mathrm{hom} e}^{p r i}+s_{\mathrm{hom} e}^{\mathrm{sec}}+\frac{1}{2} s_{\mathrm{hom} e}^{\text {ter }}\right)
$$

Where $s_{M X}^{p r i}$ would indicate the proportion of the migrants from a particular home country working in Mexico who only have primary education, and $s_{\text {home }}^{p r i}$ would indicate the proportion of the population of the home country with only primary education. For instance, if from a country where schooling is $(0.1,0.1,0.8)$ - indicating $10 \%$ have primary education, $10 \%$ have secondary education and $80 \%$ tertiary education, we have that immigrants into Mexico only have primary education, then $\mathrm{p}=0.05$. If from a country with low education $(0.8,0.1,0.1)$ all of those who reside in Mexico have tertiary education, $\mathrm{p}=0.95$. If from a country with equal proportions of educational degrees $(0.33,0.33,0.33)$ the workers in Mexico have the same proportions then we would have

\footnotetext{
${ }^{14}$ For North Korea we use South Korea, and for Macao and Taiwan we use China. For other African and Asian countries we use the scores from Tunisia which is the only country available. For Center and South America we group the data according to the three countries for which we have PISA scores: Brazil, Mexico and Uruguay. For the rest of Europe we use Greece. According to the 2015 PISA test, which was administered in more countries, we use Germany for the case of England and we use Greece for the case of Israel.
} 
$\mathrm{p}=0.5$. The proportions of immigrants in Mexico with different educational degrees we obtain directly from the data, and the proportions with the respective degrees in the home countries we obtain from the database in Docquier, Lowell and Marfouk (2009, http://www.rnim.org/uploads/1/6/3/4/16347570/dm_dataset.xls). We find countries that are geographically close, such as USA and Guatemala have p of 0.4 and 0.52 while countries that are farther away have higher values, such as Japan and Ecuador with values of 0.8. As in Hanushek et al. (2017) we then adjust PISA test scores given the value of $\mathrm{p}$ as follows:

$$
\operatorname{scoreselp}_{\mathrm{j}}=\operatorname{invnormal}\left(\mathrm{p}_{\mathrm{j}}\right) * \text { pisa_sd } \mathrm{j}_{\mathrm{j}}+\text { pisa_av }_{\mathrm{j}}
$$

where the invnormal function is the inverse of the normal, pisa_sd $\mathrm{s}_{\mathrm{j}}$ is the standard deviation of the mathematics PISA scores for country $\mathrm{j}$, and pisa_av $\mathrm{j}$ is the average score for country $\mathrm{j}^{15}$. The last two columns of Table 1A show the test scores corrected for international migration.

\footnotetext{
${ }^{15} \mathrm{We}$ also compute the values for the 75 and 90 percentiles, scoresel $75_{\mathrm{j}}=$ invnormal $(.75) *$ pisasd $_{\mathrm{j}}+$ pisaav $_{\mathrm{j}}$; and scoresel90 $0_{\mathrm{j}}=$ invnormal $(.90) *$ pisasd $_{\mathrm{j}}+$ pisaav; and the correlation coefficients between the estimated values of scoresel75, scoresel90, and the real is of 0.98 for the $75^{\text {th }}$ percentile and 0.97 for the $90^{\text {th }}$ percentile.
} 
Table 1A. PISA test scores by state, adjustment of test scores for migration between states, autoselection of migrants and international migration.

\begin{tabular}{|c|c|c|c|c|c|c|c|}
\hline (1) & (2) & (3) & (4) & $(5)$ & (6) & (7) & $(8)$ \\
\hline \multirow[t]{2}{*}{ State } & $\begin{array}{c}\text { PISA } \\
\text { Average } \\
2003-2012\end{array}$ & \multicolumn{2}{|c|}{$\begin{array}{l}+ \text { With interstate } \\
\text { migration. }\end{array}$} & \multicolumn{2}{|c|}{$\begin{array}{l}+ \text { Adjusted for } \\
\text { selective migration }\end{array}$} & \multicolumn{2}{|c|}{$\begin{array}{l}+ \text { Adjusted for } \\
\text { international migrants }\end{array}$} \\
\hline & & 2010 & 2016 & 2010 & 2016 & 2010 & 2016 \\
\hline Aguascalientes & 634 & 615 & 618 & 600 & 604 & 600 & 604 \\
\hline Baja California & 487 & 500 & 494 & 487 & 481 & 489 & 482 \\
\hline Baja California Sur & 447 & 473 & 456 & 480 & 456 & 484 & 457 \\
\hline Campeche & 370 & 380 & 380 & 384 & 384 & 386 & 385 \\
\hline Coahuila & 544 & 546 & 543 & 544 & 539 & 544 & 539 \\
\hline Colima & 544 & 543 & 542 & 536 & 534 & 536 & 534 \\
\hline Chiapas & 279 & 288 & 286 & 296 & 293 & 298 & 295 \\
\hline Chihuahua & 580 & 564 & 565 & 545 & 546 & 545 & 546 \\
\hline Cd. de México & 653 & 617 & 620 & 589 & 593 & 589 & 593 \\
\hline Durango & 527 & 530 & 529 & 531 & 528 & 531 & 528 \\
\hline Guanajuato & 546 & 549 & 548 & 551 & 550 & 551 & 550 \\
\hline Guerrero & 263 & 286 & 279 & 305 & 294 & 306 & 295 \\
\hline Hidalgo & 537 & 543 & 541 & 544 & 541 & 544 & 541 \\
\hline Jalisco & 618 & 601 & 605 & 585 & 592 & 585 & 592 \\
\hline México & 564 & 573 & 575 & 564 & 567 & 564 & 567 \\
\hline Michoacán & 506 & 509 & 508 & 511 & 507 & 511 & 508 \\
\hline Morelos & 575 & 538 & 544 & 513 & 523 & 513 & 523 \\
\hline Nayarit & 491 & 500 & 499 & 502 & 501 & 502 & 501 \\
\hline Nuevo León & 704 & 647 & 654 & 602 & 613 & 602 & 613 \\
\hline Oaxaca & 432 & 436 & 434 & 439 & 437 & 440 & 437 \\
\hline Puebla & 526 & 524 & 524 & 522 & 524 & 523 & 524 \\
\hline Querétaro & 605 & 595 & 592 & 593 & 590 & 594 & 591 \\
\hline Quintana Roo & 458 & 440 & 442 & 421 & 417 & 422 & 417 \\
\hline San Luis Potosí & 480 & 491 & 487 & 499 & 495 & 501 & 496 \\
\hline Sinaloa & 513 & 513 & 512 & 512 & 510 & 512 & 510 \\
\hline Sonora & 492 & 497 & 497 & 497 & 497 & 497 & 497 \\
\hline Tabasco & 288 & 312 & 304 & 335 & 322 & 336 & 322 \\
\hline Tamaulipas & 488 & 492 & 490 & 487 & 483 & 487 & 484 \\
\hline Tlaxcala & 440 & 462 & 457 & 476 & 470 & 476 & 470 \\
\hline Veracruz & 448 & 453 & 453 & 456 & 456 & 457 & 457 \\
\hline Yucatán & 444 & 447 & 445 & 451 & 446 & 452 & 447 \\
\hline Zacatecas & 519 & 525 & 524 & 530 & 528 & 530 & 528 \\
\hline Mean & 500 & 500 & 498 & 496 & 494 & 497 & 495 \\
\hline Standard deviation & 100 & 88 & 90 & 78 & 82 & 78 & 81 \\
\hline
\end{tabular}


Table 1B. Estimates of rates of return to schooling by state

\begin{tabular}{lc}
\hline State & Rate of Return \\
\hline Aguascalientes & 0.112 \\
Baja California & 0.120 \\
Baja California Sur & 0.087 \\
Campeche & 0.105 \\
Coahuila & 0.130 \\
Colima & 0.089 \\
Chiapas & 0.087 \\
Chihuahua & 0.117 \\
Cd. de México & 0.140 \\
Durango & 0.094 \\
Guanajuato & 0.089 \\
Guerrero & 0.074 \\
Hidalgo & 0.094 \\
Jalisco & 0.098 \\
México & 0.091 \\
Michoacán & 0.078 \\
Morelos & 0.095 \\
Nayarit & 0.075 \\
Nuevo León & 0.156 \\
Oaxaca & 0.082 \\
Puebla & 0.086 \\
Querétaro & 0.103 \\
Quintana Roo & 0.093 \\
San Luis Potosí & 0.094 \\
Sinaloa & 0.089 \\
Sonora & 0.102 \\
Tabasco & 0.094 \\
Tamaulipas & 0.122 \\
Tlaxcala & 0.091 \\
Veracruz & 0.097 \\
Yucatán & 0.087 \\
Zacatecas & 0.083 \\
\hline Mean & \\
Variance & \\
\hline & 0.003 \\
\hline
\end{tabular}


Table 2B. 2010 Human capital estimates using the multiplicative model.

\begin{tabular}{lcc}
\hline & OLS & Instruments \\
\hline Aguascalientes & 5.24 & 5.14 \\
Baja California & 5.33 & 5.24 \\
Baja California Sur & 5.03 & 4.93 \\
Coahuila & 5.47 & 5.37 \\
Colima & 5.01 & 4.92 \\
Chiapas & 4.72 & 4.63 \\
Chihuahua & 5.27 & 5.17 \\
Cd. de México & 5.64 & 5.55 \\
Durango & 5.03 & 4.93 \\
Guanajuato & 4.90 & 4.80 \\
Guerrero & 4.71 & 4.62 \\
Hidalgo & 4.96 & 4.87 \\
Jalisco & 5.09 & 4.99 \\
México & 5.03 & 4.94 \\
Michoacán & 4.73 & 4.63 \\
Morelos & 5.09 & 4.99 \\
Nayarit & 4.82 & 4.72 \\
Nuevo León & 5.68 & 5.58 \\
Oaxaca & 4.73 & 4.63 \\
Puebla & 4.87 & 4.78 \\
Querétaro & 5.18 & 5.08 \\
Quintana Roo & 5.07 & 4.97 \\
San Luis Potosí & 5.04 & 4.95 \\
Sinaloa & 5.07 & 4.97 \\
Sonora & 5.17 & 5.08 \\
Tamaulipas & 5.36 & 5.26 \\
Tlaxcala & 5.00 & 4.90 \\
Veracruz & 4.98 & 4.89 \\
Yucatán & 4.90 & 4.80 \\
Zacatecas & 4.83 & 4.74 \\
\hline Mean & 5.25 & 4.25 \\
Std. Dev. & & \\
\hline & & \\
\hline
\end{tabular}


Table 3B. Estimates of Human Capital using the Additive model.

\begin{tabular}{|c|c|c|}
\hline & $\begin{array}{c}\text { Standardized difference } \\
\text { in PISA test } \\
\text { (Quality Measure) }\end{array}$ & $\begin{array}{c}\text { Human Capital (h) } \\
\text { Additive model }\end{array}$ \\
\hline Aguascalientes & 3.81 & 1.46 \\
\hline Baja California & 2.41 & 1.20 \\
\hline Baja California Sur & 2.35 & 1.23 \\
\hline Campeche & 1.10 & 0.95 \\
\hline Coahuila & 3.11 & 1.35 \\
\hline Colima & 3.00 & 1.29 \\
\hline Chiapas & 0.00 & 0.59 \\
\hline Chihuahua & 3.12 & 1.30 \\
\hline Cd. de México & 3.67 & 1.54 \\
\hline Durango & 2.94 & 1.27 \\
\hline Guanajuato & 3.20 & 1.24 \\
\hline Guerrero & 0.09 & 0.69 \\
\hline Hidalgo & 3.10 & 1.25 \\
\hline Jalisco & 3.62 & 1.38 \\
\hline México & 3.35 & 1.35 \\
\hline Michoacán & 2.68 & 1.12 \\
\hline Morelos & 2.71 & 1.25 \\
\hline Nayarit & 2.58 & 1.21 \\
\hline Nuevo León & 3.84 & 1.50 \\
\hline Oaxaca & 1.78 & 0.94 \\
\hline Puebla & 2.83 & 1.18 \\
\hline Querétaro & 3.73 & 1.43 \\
\hline Quintana Roo & 1.59 & 1.05 \\
\hline San Luis Potosí & 2.54 & 1.19 \\
\hline Sinaloa & 2.70 & 1.27 \\
\hline Sonora & 2.51 & 1.24 \\
\hline Tabasco & 0.47 & 0.87 \\
\hline Tamaulipas & 2.39 & 1.22 \\
\hline Tlaxcala & 2.24 & 1.15 \\
\hline Veracruz & 2.00 & 1.04 \\
\hline Yucatán & 1.94 & 1.06 \\
\hline Zacatecas & 2.92 & 1.22 \\
\hline Mean & 2.51 & 1.19 \\
\hline Variance & 1.00 & 0.04 \\
\hline
\end{tabular}

